\author{
Michał Przybylski \\ Katedra Socjologii Stosowanej i Pracy Socjalnej \\ Uniwersytet Łódzki \\ przybylski_michal@wp.pl
}

\title{
Hejterstwo: przejaw wiedzy czy niewiedzy? Analiza wypowiedzi internautów w odniesieniu do zjawiska ubóstwa
}

\section{Wprowadzenie}

Ubóstwo jest problemem, którego doświadczają mieszkańcy wszystkich państw niezależnie od położenia geograficznego i stopnia ich rozwoju. Według danych Eurostatu, w 2014 roku w 28 krajach Unii Europejskiej na granicy ubóstwa i ekskluzji społecznej było około 24,5\% mieszkańców krajów członkowskich ${ }^{1}$. Oznacza to, że blisko 130 milionów osób żyje w warunkach zagrażających znalezieniem się na marginesie społeczeństwa. W przypadku Polski możemy mówić o około 2,8 miliona osób znajdujących się w skrajnym ubóstwie, co oznacza realne zagrożenie dla zdrowia psychiczno-fizycznego i rozwoju człowieka (wykres 1). Z kolei poniżej granicy dochodów uprawniających do świadczeń pieniężnych z systemu pomocy społecznej znajdowało się ok. 4,5 miliona Polaków.

\footnotetext{
1 Eurostat, People at risk of poverty or social exclusion by age and sex.
} 


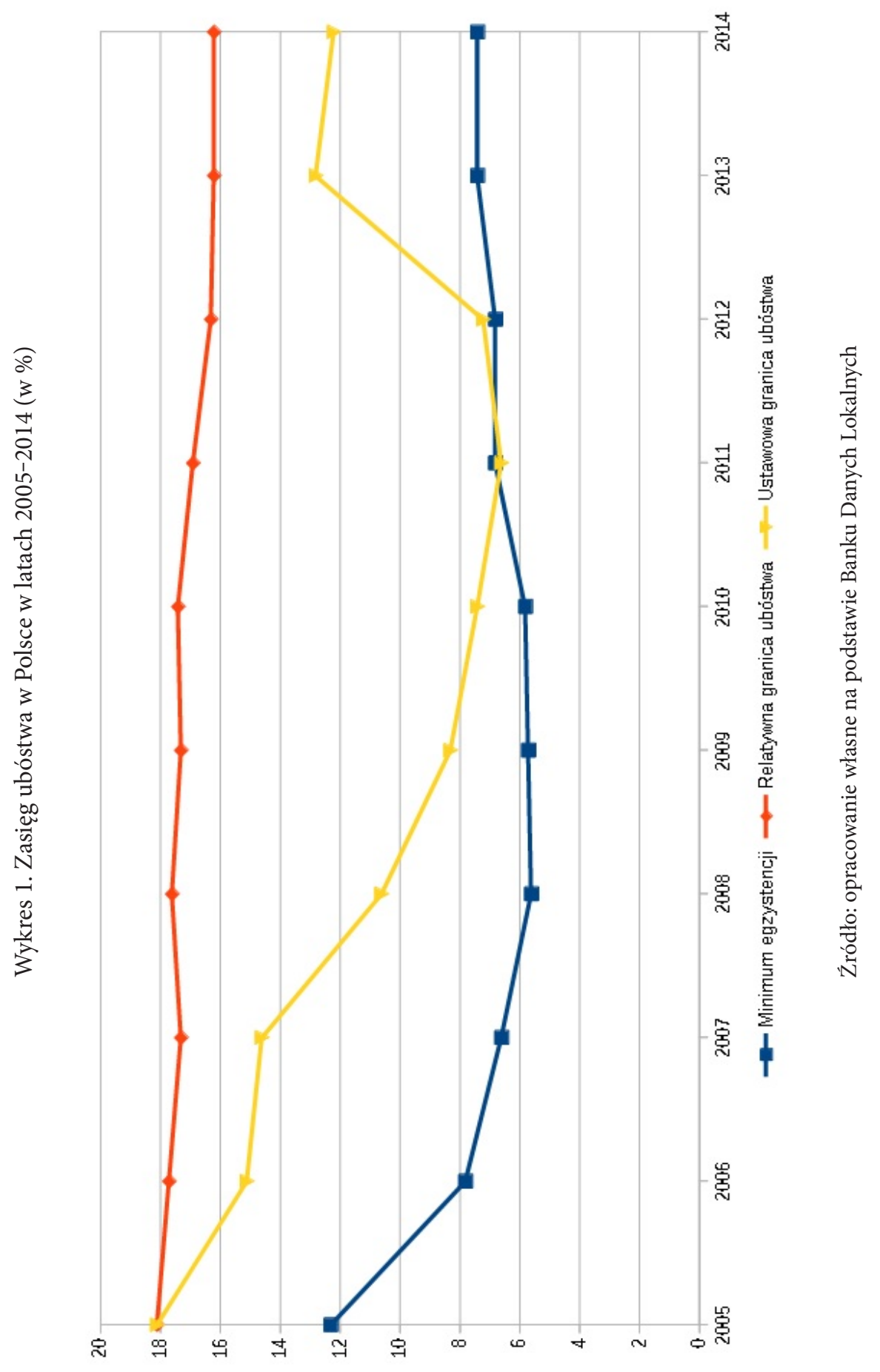


W związku z tym, że życia w warunkach biedy doświadczają tak duże grupy osób, istotnym zagadnieniem $\mathrm{z}$ perspektywy badaczy nauk społecznych stały się analizy sposobów mówienia o osobach ubogich przez przedstawicieli świata mediów, polityki, a współcześnie także pozornie tylko anonimowych internautów. Celem artykułu jest analiza negatywnych i krzywdzących wypowiedzi o osobach korzystających $z$ instytucji pomocy społecznej i świadczeń pieniężnych i niepieniężnych przeprowadzona na podstawie komentarzy do artykułów opublikowanych na portalu „Dziennik Łódzki” odnoszących się przede wszystkim do regionu lódzkiego ${ }^{2}$.

\section{Hejterstwo czy mowa nienawiści?}

Jako że w artykule będzie wykorzystywane pojęcie „hejterstwa”, dalsze rozważania należy poprzedzić pewnym wyjaśnieniem. Marta Juza definiuje hejterstwo jako: „formę dewiacyjnych zachowań podczas publicznych dyskusji internetowych” polegających na „używaniu obelżywego języka, pogardliwej ocenie różnych zjawisk, znieważaniu zarówno rozmówców jak i różnych innych podmiotów oraz na wyrażaniu agresji i nienawiści pod ich adresem" (Juza 2015: 29). Wyrażanie nienawiści w stosunku do kogoś, na co zwraca uwagę cytowana autorka, nasuwa skojarzenia z mową nienawiści, która została zdefiniowana w 1997 roku przez Radę Europy. W przyjętej rezolucji jest ona rozumiana jako: „wszystkie formy wypowiedzi, które upowszechniają, wzniecają, promują lub uzasadniają nienawiść na tle rasowym, ksenofobię, antysemityzm i inne formy nienawiści mające swoje źródło w nietolerancji” (Council of Europe 1997: 107). Nie będzie więc nadużyciem stwierdzenie, że hejterstwo jest mową nienawiści przejawiającą się w sferze internetowej. W związku z tym w dalszej części artykułu oba te określenia będą stosowane naprzemiennie $^{3}$.

2 Serwis został przede wszystkim ze względu na ograniczoną i mało skuteczną moderację, która w przypadku innych stron internetowych usuwa wpisy łamiące ich regulamin.

3 Argumentem przemawiającym za tym podejściem jest także to, że pojęcie hejterstwa może umniejszać wagę zjawiska, które jest de facto krzewieniem nienawiści do określonych grup etnicznych, religijnych, ale również do mniejszości - na przykład seksualnych lub też klientów pomocy społecznej, jak w przypadku niniejszego tekstu. 


\section{Sposoby mówienia o ubóstwie i osobach żyjących w nim}

Ruth Lister podkreśla, że bieda nie jest tylko zjawiskiem ograniczonym do zagadnień materialnych, ale stanowi również swoistą relację społeczną pomiędzy osobami znajdującymi się w ubóstwie a „nie-biednymi” (Lister 2007: 125). Pomimo dwukierunkowości tej relacji, to przede wszystkim osoby pozostające poza kręgami biedy i wykluczenia społecznego decydują o sposobie definiowania i mówienia o ludziach doświadczających biedy. To sprawia, że „nie-biedni” mają możliwość realnego wpływu na życie tych, którzy znajdują się w złej sytuacji materialnej, poprzez ustalanie granic normalności i podtrzymywanie ich. Jednocześnie ci, którzy znajdują się w lepszej sytuacji materialnej, mogą swoimi wypowiedziami pogłębiać istniejące różnice pomiędzy tymi dwiema grupami i nadawać im niewspółmiernie duże znaczenie. Temu różnicowaniu daleko jest do neutralnego, ponieważ charakteryzuje się przedstawianiem osób ubogich jako stanowiących zagrożenie, moralnie zepsutych, wywołujących litość czy też będących ekonomicznym balastem dla społeczeństwa (Lister 2007: 126). Żeby w pełni zobrazować siłę wpływu „nie-biednych” na „biednych”, warto przytoczyć cytowanego przez Lister Marka Edelmana, który stwierdza, że:

procesy klasyfikacji i kategoryzacji — będące wynikiem działania instytucji rządowych i prawnych, mediów, badaczy społecznych (...) mogą wykorzystywać stereotypy, a tym samym wzmacniać je. Mogą one mieć także wpływ na sposób traktowania ludzi dotkniętych biedą, zarówno przez współobywateli, jak i przez różne wpływowe instytucje. (Edelman za: Lister 2007: 127)

W silnie asymetrycznej relacji „biedni”-„,nie-biedni” symboliczną władzę posiada więc ta druga kategoria.

Analizując dyskurs wokół klientów pomocy społecznej, można wymienić cztery strategie dyskursywne stygmatyzujące osoby korzystające ze wsparcia instytucji publicznych (Kudlińska 2012: 180-181). Pierwsza z nich polega na nadawaniu piętna zależności, co przedstawia osoby korzystające z pomocy społecznej jako bierne i długotrwale utrzymujące się z niezarobkowych źródeł - w tym przypadku ze świadczeń pieniężnych. Osoby korzystające z tej strategii de facto oskarżają osoby żyjące w ubóstwie o to, że same są sobie winne. Jednocześnie pojawia się tutaj także oskarżenie wysuwane w stosunku do systemu pomocy społecznej, któremu zarzuca się, że samym swoim istnieniem podtrzymuje obecność w społeczeństwach osób niezaradnych życiowo. Następnie możemy mówić o piętnie uzależnienia, które ma ścisły związek z pierwszą strategią dyskursywną. W jego przypadku prezentowany jest pogląd, że klienci pomocy społecznej to niemalże 
narkomani lub alkoholicy, którzy są tak silnie uzależnieni od wsparcia ze strony instytucji publicznych, że oderwani od niego nie byliby sobie w stanie samodzielnie poradzić. Fundamentem dla tej strategii dyskursywnej są przede wszystkim stereotypy i uogólnienia rozciągane na wszystkie osoby żyjące w ubóstwie. Trzecią strategią stygmatyzującą jest piętno złego prowadzenia się, odnoszące się do kobiet korzystających z pomocy społecznej. Sprowadza się ono do tworzenia wizerunku klientek instytucji wsparcia jako kobiet niemoralnych i wręcz odrażających, których sposobem na życie pozostają świadczenia pieniężne na kolejne dzieci z nieślubnych związków. Iwona Kudlińska opisując tę strategię, puentuje ją stwierdzeniem: „przez konserwatywnych publicystów pomoc społeczna dla samotnych matek jest postrzegana jako premia za rozwiązłość" (Kudlińska 2012: 181). Oczywiście powyższe poglądy nie są podparte żadnymi danymi empirycznymi. Ostatnią strategią jest piętno nieślubnego urodzenia przedstawiające dzieci klientek pomocy społecznej jako mniej warte i gorsze ze względu na środowisko swojego urodzenia. Jednocześnie, tak jak w piętnie złego prowadzenia się, takie mówienie o najmłodszych jest oparte na stereotypizacji i generalizacji.

\section{Osoby ubogie a mowa nienawiści}

W odniesieniu do omówionych strategii dyskursywnych, przedstawione teraz zostaną wybrane komentarze internautów, odnoszące się do osób żyjących w ubóstwie i systemu pomocy społecznej. Wszystkie one będą prezentowane $\mathrm{w}$ formie niezmienionej. Pierwsza grupa wypowiedzi odnosi się do piętna zależności i uzależnienia:

podobno miał być elektroniczny system kontroli wypłaty zasiłków? Jak sami pisaliście były przypadki, że niektórzy dostawali z różnych źródeł 4000 zł/mc! Większość normalnych ludzi pracuje za mniejsze, a nawet dużo mniejsze pieniądze. Ale głos „żulerni» jest na wyborach warty tyle samo, co tych, co ciężko pracują i nikt im nic nie daje...

Autor tego wpisu przytacza wcześniej przeczytany artykuł, w którym pojawiły się informacje o części osób pobierających świadczenia pieniężne i prawdopodobnie dopuszczających się nadużyć. Dokonana generalizacja prowadzi jednak do wniosku, że „żulernia” otrzymuje bez żadnego wysiłku zapomogi, które zdecydowanie przewyższają przeciętne wynagrodzenia osób utrzymujących się z pracy zarobkowej. W kolejnym wpisie pojawia się charakterystyczne dla piętn zależności i uzależnienia oskarżenie systemu pomocy społecznej o „produkowanie” osób bezrobotnych i niezaradnych życiowo: 
Państwo rozleniwiło społeczeństwo. Te wszystkie zasiłki i zapomogi ograniczają najpiękniejszą cechę Polaków- zaradność. Wiem, że po tym co napiszę dostane dużo minusów, ale taka jest prawda: Jak ktoś chce to znajdzie pracę (nie mówię o ludziach po politologii czy dziennikarstwie) szczególnie ci którzy nie maja co wrzucić do gara. Zawsze znajdzie sie jakieś sprzątanie, składanie długopisów czy c os podobnego. Na jedzenie wystarczy. PAŃSTWO ROZLENIWIŁO NIEROBÓW I NISZCZY ZARADNOŚĆ DAJĄ PIENIĄDZE ZA NIC. ZLIKWIDOWAĆ URZĘDY PRACY!!!

W powyższych słowach, które są według autora faktem, pojawia się zarzut nie tylko odnoszący się do rzekomego rozleniwienia klientów pomocy społecznej, ale nawet całego społeczeństwa polskiego, którego zaradność i pracowitość miały zostać ograniczone przez systemy państwa opiekuńczego. Osoba komentująca jest również reprezentantem dość powszechnego poglądu, że jakaś praca zawsze się znajdzie, jeżeli tylko podejmie się starania poszukania jej ${ }^{4}$. W tego typu wypowiedziach nie podnosi się jednak kwestii jakości oferowanej pracy i wysokości wynagrodzeń (według autora komentarza, adekwatna jest płaca pozwalająca kupić jedzenie), jak również zapomina się o tym, że niektóre grupy społeczne mają ograniczoną możliwość zatrudnienia (np. osoby z niepełnosprawnościami, mieszkańcy małych miejscowości, rodzice samotnie wychowujący dzieci). Do zbioru pejoratywnych określeń odnoszących się do osób żyjących w warunkach ubóstwa autor kolejnego wpisu dokłada kolejne:

PO CO W LODZI SA MENELE? Aby pracownicy mops mieli prace...

Wspomniani „menele” swoim byciem mają zapewniać argumenty przemawiające za potrzebą istnienia instytucji pomocowych, w tym przypadku Miejskiego Ośrodka Pomocy Społecznej. Jak wynika z wypowiedzi kolejnego internauty, nie tylko klienci są balastem dla gospodarki i społeczeństwa:

Nadal nie rozumiem tych pasożytów z MOPS. Walczą o pieniądze dla siebie, a nie dla tych dla których zostali powołani. Oni nie mogą się utrzymać za 1600 zł, a podopieczny za 271 zł się utrzyma ?. Niech swoją pensję tratują tak jak to mówią swoim podopiecznym: to jest DOFINANSOWANIE. Resztę niech sobie dorobią gdzie indziej. Rozgonić to i tyle. Przekazać do Urzędów Pracy, bo i tak bez rejestracji w Urzędzie pomocy nie będzie. Zostaną pieniądze na inne cele.

4 Rzecz nie dotyczy z jakiejś przyczyny absolwentów politologii i dziennikarstwa, którzy prawdopodobnie także stali się obiektem stereotypizacji i uogólnień dotyczących trudności ze znalezieniem pracy doświadczanych przez osoby kończące te kierunki. 
Autor komentarza obraził pracowników zatrudnionych w MOPS-ie $\mathrm{e}^{5}$, ale również - co jest dość zastanawiające - zrównał wynagrodzenie otrzymywane za wykonywaną pracę z zasiłkiem z zakresu pomocy społecznej, łącząc w ten sposób dwa zupełnie różne porządki. Nadawanie piętna zależności i piętna uzależnienia jest jednak bardzo wyraźne, a skrajnym przykładem wykorzystania tych strategii jest poniższy komentarz mogący budzić niesmak:

DO OBOZÓW PRACY PATOLOGIE I NYGUSOW. ZLIKWIDOWAĆ A BANDE NIEROBOW ZAGONIC DO PRACY GDZIE SA KONTROLE NAD CWANIACZKAMI CO POBIERAJA ZASILKI? PAŃSTWO ROZPUSCILO LESEROW I ZA DARMO KASE ROZDAJA TYLKO CZEMU KUR.WA Z MOICH PODATKÓW? PTOLOGIE TO TRZEBA JEB.AC.

„Patologia” i „nygusy” powinni zostać wysłani do obozów pracy, co może wywoływać uzasadnione skojarzenia $\mathrm{z}$ historycznymi systemami totalitarnymi i obecnymi w nich praktykami. Ponadto po raz kolejny pojawia się zarzut, że państwo, swoim „rozdawnictwem” pieniędzy pochodzących $\mathrm{z}$ danin płaconych przez autora, doprowadziło do powstania grupy „leserów”, którzy dzięki zasiłkom pieniężnym nie muszą pracować.

Kolejne dwa wpisy odnoszą się do piętn złego prowadzenia się i nieślubnego urodzenia. W pierwszym $\mathrm{z}$ nich, zamieszczonym pod artykułem dotyczącym starań dyrekcji Domu Samotnej Matki o zwiększenie dotacji z Miejskiego Ośrodka Pomocy Społecznej, autor zdecydowanie stwierdza:

LAPY PRECZ OD PIENIEDZY PODATNIKOW. niech KK finansuje to gniazdo upadłych kobiet...

Internauta powiela stereotyp klientek pomocy społecznej samotnie wychowujących dzieci jako kobiet niemoralnych, próbując jednocześnie przerzucić odpowiedzialność finansowania instytucji pomocowej z samorządu i władzy centralnej na Kościół katolicki. W powyższej krótkiej wypowiedzi nie pojawia się w ogóle odniesienie do sytuacji, w jakiej znajdują się dzieci samotnych matek. Kolejny internauta przedstawił swoje przemyślenia na ten temat:

Jeśli rodzic woli wydać pieniądze na tytoń, czy alkohol, to dziecko chodzi głodne. Ale jeśli będziemy takim dzieciom pomagać, to niedługo wszystkie wydatki na to dziecko będzie ponosić państwo z naszych podatków. Już fundujemy obiady, zaraz będą śniadania,

5 Łódzcy terenowi pracownicy socjalni domagali się wówczas podwyżek swoich relatywnie niskich uposażeń (zob. np. MOPS w Łodzi o proteście pracowników socjalnych 2014). 
bywa mleko, owoce, jest wyprawka szkolna, może jakieś ubrania... Pełne utrzymanie. Potem ktoś naprawdę biedny widzi, że zupełnie niepotrzebnie się stara, bo lekkoduchy dostają tak wiele za darmo. I też wyciąga rękę. A może zmusić tych rodziców, by się zajęli SWOIMI dziećmi?

Rodzi się pytanie, czy osoba pisząca powyższe słowa była w pełni świadoma treści wpisu zamieszczonego pod jednym z artykułów. Stwierdziła wprost, że dzieciom głodnym (z winy rodziców, którzy zamiast jedzenia kupują wyroby tytoniowe i alkohol) państwo nie powinno pomagać, ponieważ w ten sposób prowadzi się do rozbudzenia oczekiwań innych rodziców związanych ze świadczeniami pieniężnymi i niepieniężnymi. Powyżej opisane strategie dyskursywne mogą zostać również rozwinięte o jeszcze jeden typ wypowiedzi, które w całości negują istnienie zjawiska ubóstwa w Polsce ${ }^{6}$ :

Kilka lat temu (jakieś 7-10) był reportarz w tv zrealizowany prze Niemców, co to przyjechali do Polski sfilmować polskie ubóstwo. Reportaż nie sprostał zakładanej tezie, bo się okazało, że na każdym domu w polskiej wsi jest co njamniej jedna antena satelitarna, przy każdym domu stoi co najmniej jedno auto, każdy dom ma całkiem niezłe gospodarstwo. I nici z propagandy.

Z powyższej wypowiedzi nie można wywnioskować, jaki dokładnie reportaż autor ma na myśli, ale widoczne jest uogólnienie sprowadzające się do tego, że wszyscy mieszkańcy obszarów wiejskich w kraju są osobami, których nie można zaliczyć do grupy żyjącej w warunkach ubóstwa. Zjawisko biedy może zostać zanegowane również w inny sposób, co pokazuje kolejny wpis:

W Polsce biedy nie ma, mówią o niej ci co nie chcą podjąć pracy bo od kilkunastu lat żerują na socjalu, jest duża grupa ludzi którzy nigdy nie będą pracować, bo po co pienądze wyłudzą z Mops-ów.To ci krzyczą o swojej biedzie

Jego autor wyraża wskazane już wcześniej przekonanie, że w Polsce nie istnieją ludzie ubodzy - można mówić tylko o osobach leniwych, niezmotywowanych i biernych zawodowo, utrzymujących się z niesprawiedliwie przyznanych świadczeń pieniężnych. Ostatni sposób zaprzeczenia istnienia osób żyjących w warunkach ubóstwa sprowadza się w gruncie rzeczy do tego, że jeżeli ma się cokolwiek, to nie jest się biednym. Za przykład niech posłuży poniższy wpis:

6 Odrębnym tematem badawczym byłaby próba odpowiedzenia na pytanie, w którym momencie elity symboliczne zaczęły negować istnienie osób ubogich. Nawiązuję w tym miejscu między innymi do wypowiedzi byłej premier Ewy Kopacz, która w okresie kampanii wyborczej w 2015 roku zarzucała kłamstwo oponentom politycznym mówiącym o problemie głodnych dzieci w Polsce (zob. np. Kopacz: Mówienie o głodnych polskich dzieciach służy rosyjskiej propagandzie 2015). 
$\mathrm{Na}$ internet macie pieniacze? To nie jesteście biedni.

Przed napisaniem tego typu słów warto byłoby pomyśleć o tym, że współcześnie dostęp do komputera i internetu bardzo się upowszechnił, co spowodowało relatywny spadek kosztów dostępu do podstawowych technologii cyfrowych. Jednocześnie postępująca cyfryzacja sprawiła, że nieposiadanie internetu utrudnia dostęp do różnych usług, które z punktu widzenia osób żyjących w ubóstwie mogłyby przyczynić się do poprawy ich sytuacji ${ }^{7}$.

Widoczne w przywołanych przykładach budowanie dystansu pomiędzy ubogimi a bogatymi, tworzenie negatywnego wizerunku ubóstwa i wykazywanie własnej wyższości moralnej nad tymi, którzy znajdują się w gorszej sytuacji materialnej, ma określone przyczyny. Od XVI wieku coraz większą popularność zdobywały idee protestanckie głoszące etos ciężkiej i uczciwej pracy. Można więc stwierdzić, że to właśnie w tamtym okresie zaczęto postrzegać osoby ubogie w kategoriach winy (Woźniak 2010: 199). W kolejnych wiekach, wraz z rozwojem systemów kapitalistycznych, sytuacja osób biednych coraz częściej uzasadniana była nie czynnikami instytucjonalnymi, ale cechami indywidualnymi - przede wszystkim lenistwem i niezaradnością. Stworzony mit pucybuta, który tylko dzięki własnym zasługom zostaje milionerem, doprowadził do postrzegania sukcesu w życiu głównie przez pryzmat posiadanych pieniędzy (Woźniak 2010: 199). Nie bez wątpliwych zasług dla sposobu postrzegania osób ubogich i mówienia o nich jest środowisko akademickie. Od połowy lat 50. ubiegłego wieku dostarczało ono tez mówiących o pozytywnym wpływie nierówności dochodowych na rozwój społeczeństw, w myśl których zagrożenie ubóstwem miało stanowić motywację do pracy i rozwoju osobistego. Ten sposób narracji został przejęty przez media. Przyczyniły się one do „naznaczania odpowiednio semantycznie spreparowanym stygmatem osób na najniższych szczeblach hierarchii społecznej jako ludzi krnąbrnych, wyobcowanych, wrogich i groźnych dla zdrowej większości” (Woźniak 2010: 202). W kontekście polskim dużą rolę dla kształtowania wizerunku osoby żyjącej w warunkach ubóstwa i korzystającej ze świadczeń z systemu pomocy społecznej miały elity symboliczne po okresie transformacji. W konsekwencji doprowadzono do tego, że w zależności od roku badania, od około $30 \%$ do ponad $45 \%$ respondentów wskazywało niezaradność życiową jako przyczynę pozostawania w ubóstwie, a od niecałych $20 \%$ do ponad $40 \%$ badanych odpowiadało, że sytuacja osób niezamożnych jest konsekwencją ich lenistwa i niechęci do podejmowania pracy (wykres 2).

7 Na przykład w obszarze rynku pracy. Obecnie większość ofert pojawia się na różnych portalach internetowych, a pracodawcy oczekują od kandydatów przesyłania wymaganych dokumentów na wskazane adresy e-mail. To sprawia, że brak dostępu do internetu mocno ogranicza w poszukiwaniach pracy. 


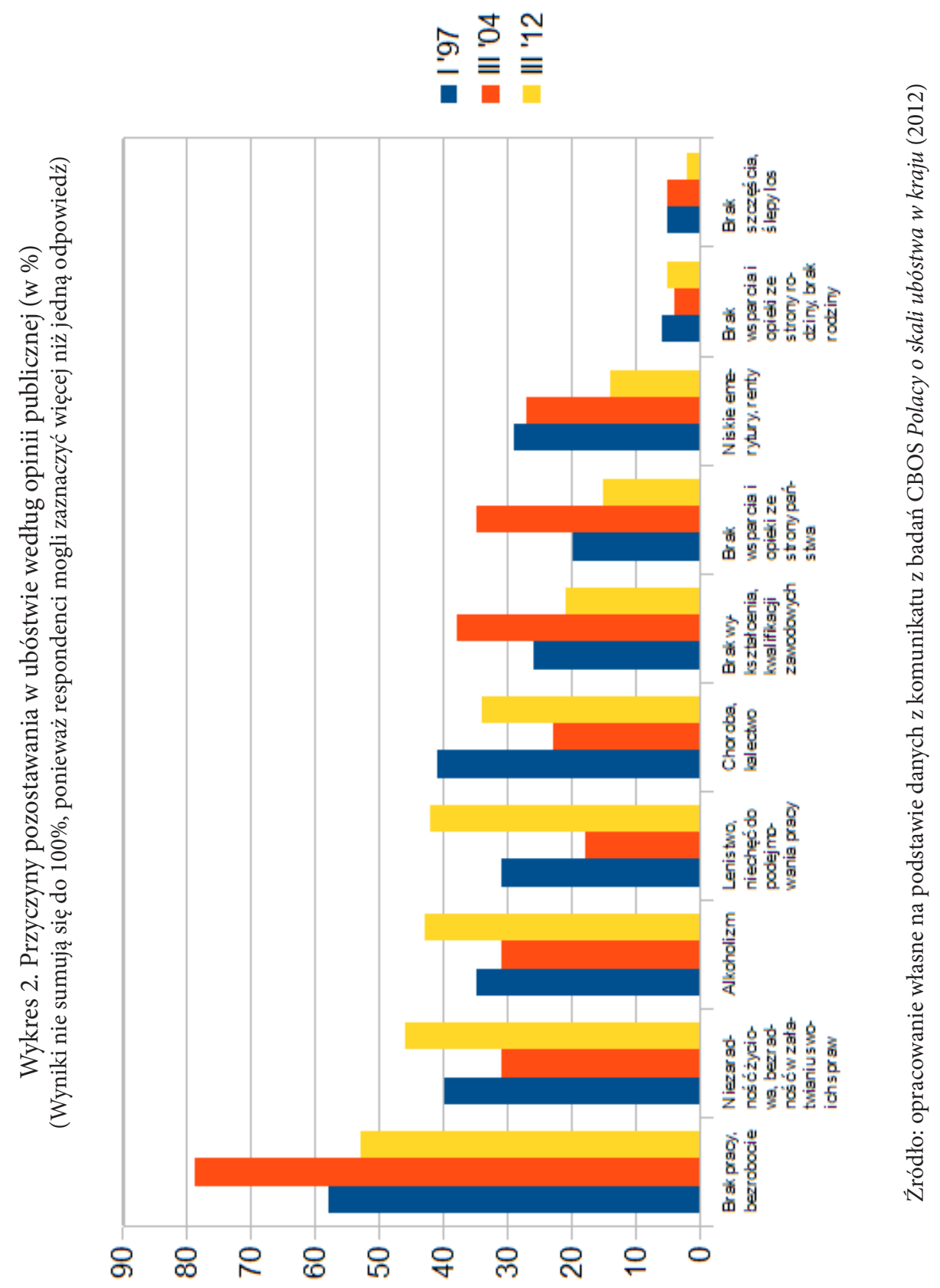


Warto podkreślić, że w ostatnim analizowanym roku odsetek respondentów wskazujących na winę osób żyjących w warunkach ubóstwa był najwyższy w badanym okresie. Pewne wyjaśnienie proponuje Ryszard Szarfenberg, który stwierdza, że w okresach wzrostu gospodarczego opinia publiczna może być bardziej skłonna do szukania przyczyn ubóstwa w cechach indywidualnych osób ubogich, natomiast $\mathrm{w}$ warunkach gorszej koniunktury wytłumaczeń dla zjawiska biedy społeczeństwo będzie doszukiwało się po stronie konstrukcji systemu społeczno-gospodarczego (Szarfenberg 2012: 13). W raporcie CBOS, na podstawie którego został przygotowany wykres 2 , można również zobaczyć, w jaki sposób objawia się linia podziałów pomiędzy „biednymi” a „nie-biednymi”. Respondenci deklarujący własne warunki materialne jako dobre zdecydowanie częściej od badanych oceniających własną sytuację materialną jako złą wskazywali na niezaradność i lenistwo jako na przyczyny pozostawania osób w ubóstwie (CBOS 2012: 8).

\section{Hejterstwo - przejaw wiedzy czy niewiedzy?}

Wracając do pytania postawionego w tytule niniejszego artykułu, trzeba podkreślić, że udzielenie na nie jednoznacznej odpowiedzi jest obecnie bardzo trudne lub wręcz niemożliwe. Pomimo tego, że o zjawisku hejterstwa sporo się współcześnie mówi i pisze, to nadal nie wiemy zbyt wiele o jego skali i osobach stosujących mowę nienawiści w internecie. $\mathrm{Z}$ badania przeprowadzonego przez firmę badawczą SW Research na próbie 800 internautów w wieku 16-64 lata wynika, że około $11 \%$ respondentów miało w swoim życiu epizod bycia hejterem (SW Research 2015). Przy czym wśród osób wyrażających się krzywdząco o innych przeważali młodzi mężczyźni do 24 roku życia zamieszkujący średnie i duże miasta, mający wykształcenie zawodowe lub średnie. Pewne wyjaśnienie motywów tego typu zachowań można znaleźć $\mathrm{w}$ raporcie $\mathrm{z}$ pilotażowego badania przeprowadzonego przez Fundację im. Stefana Batorego. Jego autorzy badali zjawisko mowy nienawiści z perspektywy mniejszości narodowych, etnicznych, religijnych i seksualnych, interesując się przede wszystkim tym, w jaki sposób przedstawiciele tych mniejszości odbierają mowę nienawiści skierowaną przeciwko nim. Badacze ustalili, że: „akceptacja mowy nienawiści, szczególnie wśród młodzieży, jest silnie związana z prawicowo-hierarchicznym światopoglądem”, a także że: „W przypadku młodzieży akceptacja mowy nienawiści wynika w większym stopniu z uprzedzeń aniżeli z umiłowania wolności słowa” (Bilewicz, Marchlewska, Soral, Winiewski 2014: 7). Z kolei w badaniu przeprowadzonym przez Monikę Czaplicką na próbie 522 osób w wieku 16-85 lat, wśród których większość stanowiły kobiety, aż 68\% 
respondentów przyznało się do stosowania mowy nienawiści (Czaplicka 2015:3). Abstrahując od bardzo dużej różnicy odsetka osób przyznających się do zachowań hejterskich w porównaniu do badania SW Research, warto zwrócić uwagę na przyczyny tego typu postaw. Około $25 \%$ hejterów stwierdziło, że mową nienawiści wyrażali negatywne emocje, podobna liczba respondentów odpowiedziała, że wyrażała w ten sposób krytyczną opinię, 15\% zadeklarowało zdenerwowanie, a dla 6\% motywację stanowiła zazdrość (Czaplicka 2015: 4). Z perspektywy przyszłych badań tego zjawiska być może najciekawszą grupę stanowią ci, którzy nie potrafili uzasadnić swojego zachowania (20\% respondentów) oraz ci, którzy nie mieli żadnego powodu, by stosować mowę nienawiści (10\% respondentów).

Jeszcze słabiej rozpoznanym zagadnieniem jest mowa nienawiści skierowana do osób doświadczających ubóstwa, wykluczonych społecznie i zagrożonych wykluczeniem. Trzeba powtórzyć, że tylko w Polsce problem ubóstwa dotyczy ponad 2 milionów osób. Żadne z przytaczanych powyżej badań nie uwzględniało kategorii osób ubogich jako grupy doświadczającej mowy nienawiści. Cytowane wcześniej badania CBOS-u pozwalają na stwierdzenie, że osoby pozostające w ubóstwie są odbierane przez znaczną część opinii publicznej w sposób negatywny. Z badań dyskursu i procesów stygmatyzacji wiadomo również, że przejawy piętnowania i umniejszania znaczenia osób znajdujących się w warunkach biedy mają pozbawiać je podmiotowości, dyskwalifikować w oczach innych, wypychać na margines całe niepożądane społecznie grupy czy też uzasadniać istnienie nierówności społecznych (Kudlińska 2012: 176-177). Pomimo tej wiedzy potrzebne są dalsze pogłębione analizy, które pomogłyby rozpoznać zjawisko hejterstwa w odniesieniu do osób ubogich i udzieliłyby jednoznacznych odpowiedzi na pytania o skalę zjawiska, profil osób stosujących mowę nienawiści, motywację, ale także o konsekwencje hejterstwa na poziomie jednostek i społeczeństw. Nierozpoznanym obszarem pozostają też doświadczenia związane $\mathrm{z}$ obecnością mowy nienawiści w internecie z perspektywy osób wykluczonych społecznie i korzystających z instytucji pomocy społecznej. Uporządkowanie i uzupełnienie dotychczasowych badań umożliwiłoby stworzenie pełnego obrazu omawianego zjawiska i wykazanie, ile jest $\mathrm{w}$ hejterstwie wiedzy, a ile ignorancji. Biorąc jednak pod uwagę stopień negatywnych emocji w przytaczanych komentarzach Internautów oraz w analizach prowadzonych przez instytucje i innych badaczy można pokusić się o stwierdzenie, że w wypowiedziach hejterów więcej jest uprzedzeń i niesprawiedliwych uogólnień niż faktycznej wiedzy z zakresu komentowanych zagadnień. 


\section{Bibliografia}

Bilewicz Michał, Marchlewska Marta, Soral Wiktor, Winiewski Mikołaj (2014), Mowa nienawiści. Raport $z$ badań sondażowych, http://www.ngofund.org.pl/ wp-content/uploads/2014/06/raport_final_poj.pdf [dostęp: 13.02.2016].

Centrum Badań Opinii Społecznej (2012), Polacy o skali ubóstwa w kraju, http:// www.cbos.pl/SPISKOM.POL/2012/K_051_12.PDF [dostęp: 13.02.2016].

Council of Europe (1997), Recommendation No. R (97) 20 of the Committee of Ministers to Member States on "hate speech”, http://www.coe.int/t/dghl/standardsetting/hrpolicy/other_committees/dh-lgbt_docs/CM_Rec(97)20_en.pdf [dostęp: 13.02.2016].

Czaplicka Monika (2015), Hejt w internecie. Raport ilościowy, http://wobuzz. com/hejt/wp-content/uploads/2015/09/raport-o-hejcie-w-sieci.pdf [dostęp: 13.02.2016].

Dyskursy ubóstwa i wykluczenia społecznego (2013), E. Tarkowska (red.), Wydawnictwo IFiS PAN.

MOPS w Łodzi o proteście pracowników socjalnych (2014) [w:] DziennikŁódzki.pl, http://www.dzienniklodzki.pl/artykul/3643610,mops-w-lodzi-o-protesciepracownikow-socjalnych-stanowisko,1,id,t,so.html [dostęp: 06.03.2016].

Kopacz: Mówienie o głodnych polskich dzieciach służy rosyjskiej propagandzie (2015) [w:] Gazeta.Pl Wiadomości, http://wiadomosci.gazeta.pl/wiadomosci /1,114871,18547444,kopacz-mowienie-o-glodnych-polskich-dzieciach-sluzy-rosyjskiej.html [dostęp: 06.03.2016].

Juza Marta (2015), Hejterstwo w komunikacji internetowej: charakterystyka zjawiska, przyczyny i sposoby przeciwdziałania, „Profilaktyka społeczna i resocjalizacja”, nr 25.

Kudlińska Iwona (2012), Stygmatyzacja społeczna jako strategia dyskursywna biedy $i$ jej rola w procesie wykluczenia społecznego, „Kultura i społeczeństwo”, nr 1. Lister Ruth (2007), Bieda, Wydawnictwo Sic!, Warszawa.

SW Research (2015), Hejterzy w sieci, http://swresearch.pl/news/czytaj/id/110/ hejterzy-w-sieci [dostęp: 13.02.2016].

Szarfenberg Ryszard (2012), Ubóstwo i wykluczenie społeczne w Polsce - pomiar, wyjaśnienie, strategie przeciwdziałania, http://rszarf.ips.uw.edu.pl/pdf/uiws2012a.pdf [dostęp: 13.02.2016].

Woźniak Wojciech (2010), Zwalczanie ubóstwa czy zwalczanie ubogich? O wizerunku biednego w polskim dyskursie publicznym [w:] Podziały klasowe i nierówności - Refleksje socjologiczne po dwóch dekadach realnego kapitalizmu w Polsce, P. Żuk (red.), Oficyna Naukowa, Warszawa. 


\title{
Michał Przybylski
}

\section{Hejterstwo: przejaw wiedzy czy niewiedzy? Analiza wypowiedzi internautów w odniesieniu do zjawiska ubóstwa}

\author{
Hate Acts: Indication of Knowledge or Ignorance? Analysis of \\ Expression of Internet Users in Relation to the Phenomena of Poverty
}

Słowa kluczowe: ubóstwo, mowa nienawiści, wykluczenie społeczne, stygmatyzacja społeczna

Key words: poverty, hate speech, social exclusion, social stigma

\section{Streszczenie}

Celem artykułu jest analiza negatywnych komentarzy do artykułów odnoszących się do osób ubogich wspieranych przez instytucje pomocy społecznej i korzystających ze świadczeń pieniężnych i niepieniężnych. Podjęta została próba zmierzenia się z pytaniem, czy internauci decydujący się na stosowanie języka nienawiści $\mathrm{w}$ stosunku do grup zagrożonych wykluczeniem społecznym robią to $\mathrm{w}$ oparciu o posiadaną wiedzę na temat zjawiska, czy też powielają stereotypy dotyczące osób żyjących w warunkach biedy.

\begin{abstract}
The article aims to analyze the negative comments on online articles related to the people in poverty supported by social welfare institutions and receiving monetary and non-monetary benefits. An attempt will be made to face the question whether Internet users who decide to use hate speech toward groups at risk of social exclusion do it on the basis of their knowledge about the phenomenon or they are reproducing stereotypes about people living in the conditions of poverty.
\end{abstract}

